\title{
BURUH TANI WANITA PANGGILAN DAN EKSISTENSINYA MENURUT ADAT MINANGKABAU
}

\author{
Helfi \\ Institut Agama Islam Negeri Bukittinggi \\ e-mail: helfistain@yahoo.com
}

\begin{abstract}
Women farm workers in groups are not common in Minangkabau, especially those who earn wages once a year. The wages are used as an alternative income by allocating them as a capital for other 'business' in solving economic household problems. Minangkabau implement matrilineal system which respect women called as bundo kanduang. A local proverb for the system is "limpapeh rumah nan gadang, amban puruak pagangan kunci, sumarak dalam nagari". Discussions about women have not been finished yet. The highest reward toward women in Minangkabau custom is not well-implemented in the real life. The Minang 'queens' are allowed to compete in economic sector without any gender consideration.
\end{abstract}

Buruh tani wanita panggilan di Minangkabau secara umum tidak lazim ada, apalagi mereka yang mendapatkan upah setahun sekali. Yang lebih menarik lagi, upah yang mereka terima kemudian dijadikan sebagai modal usaha untuk mengatasi ekonomi rumah tangga. Di Minangkabau, posisi perempuan mendapatkan tempat yang terhormat, sebagaimana yang diungkapkan dalam pepatah "bundo kanduang limpapeh rumah nan gadang, amban puruak pagangan kunci, sumarak dalam nagari". Pembicaraan tentang perempuan hingga hari ini tidak kunjung berhenti. Penghargaan tertinggi kepada perempuan di Minangkabau secara adat tidak tercermin dalam kehidupan nyata. "Ratu-ratu" Minang ini dibiarkan berkompetisi secara bebas dalam pertarungan ekonomi yang tidak melihat jenis kelamin.

Keywords: workers women, economic family, poverty 


\section{Pendahuluan}

Harapan mendapatkan pekerjaan dengan perlakuan yang adil dan mampu menyejahterakan secara ekonomi merupakan dambaan setiap orang, tidak terkecuali bagi perempuan yang bekerja sebagai buruh tani di daerah pedesaan, seperti yang terdapat di Nagari Canduang, Kabupaten Agam, Sumatera Barat. Target MDGS (millennium development goals) yang dicanangkan PBB intinya adalah memberantas kemiskinan dan kelaparan ekstrim sampai tahun 2015. Target tersebut termasuk juga menyasar masyarakat desa yang tidak tersentuh program-program pemerintah, di antaranya kalangan buruh tani. Latar belakang budaya matrilineal yang meninggikan posisi perempuan di Minangkabau seharusnya juga tidak menyebabkan munculnya komunitas-komunitas buruh tani perempuan, apalagi pekerja kuli yang dibayar sekali dalam setahun. Dalam budaya Minangkabau, ada pepatah yang mengungkapkan, "bundo kanduang limpapeh rumah nan gadang, umbun puro pegangan kunci, hiasan di dalam kampuang, sumarak dalam nagari," artinya perempuan mempunyai peranan yang sangat penting dalam rumah gadang. Termasuk mengelola keuangan rumah tangga atau peran dalam lingkungan yang lebih luas, seperti dalam nagari.

Pekerjaan kaum hawa ini lambat laun mulai tidak seindah dulu. Desakan ekonomi kemudian mulai menggeser posisi perempuan. Apalagi perempuan yang tidak memiliki harta benda dan kurang mendapatkan perhatian niniak mamak nan saparui atau nan sajangka dari pihak laki-laki (paman kandung dari garis ibu). Mereka berjuang sendiri dalam persoalan ekonomi, tidak terkecuali menjadi tulang punggung ekonomi rumah tangga. Ada pepatah Minang yang mengungkapkan "adat basandi syara', syara' basandi kitabullah, syara' mangato adat mamakai”. Filsafat ini di Minangkabau secara operasional memberikan perlindungan terhadap kaum perempuan. Pesan ini berasal dari syara' kemudian diterima oleh adat sebagai perlindungan ekonomi dari suami atau laki-laki dari keluarga besar perempuan dan konsep adat Minangkabau. Secara konsep, kultur Minangkabau meninggikan posisi perempuan. Namun kenyataannya, mereka dibiarkan berkompetisi bebas dalam ekonomi global. Sehingga perlu membicarakan komunitas buruh tani dalam konsepsi adat Minangkabau. Terlebih disebutkan bahwa lebih banyak perempuan dibandingkan pria yang mengalami kemiskinan, baik relatif maupun absolut (Britha Mikkelsen, 2011:177).

el Harakah Vol.17 No.1 Tahun 2015 


\section{Munculnya Komunitas Buruh Tani Wanita Panggilan dari Lasi dan Canduang Kabupaten Agam}

Nagari Canduang dan Lasi dahulu merupakan satu pemerintahan kecamatan, yaitu Kecamatan Ampek Angkek Canduang. Setelah pemekaran, kecamatan ini berkembang menjadi dua kecamatan, yaitu Kecamatan Canduang dan Kecamatan Ampek Angkek yang berinduk pada pemerintahan Kabupaten Agam. Daerah Lasi dan Candung termasuk daerah subur karena berada di lereng dan kaki pengunungan. Dua daerah ini merupakan sentra hortikultura seperti kol, sawi, cabe, terong, jagung, ubi jalar dan lain-lain. Petani juga memiliki tanaman keras seperti kulit manis, alpukat, cengkeh, kayu surian, dan seterusnya.

Buruh tani panggilan yang mayoritas terdiri dari ibu-ibu dari daerah lereng Gunung Merapi kebanyakan berasal dari daerah Canduang dan Lasi kabupaten Agam (Wawancara dengan Joni, 12 Juli 2013). Satu kelompok biasanya terdiri dari 6 hingga 15 orang dengan satu orang yang berperan sebagai koordinator kelompok. Satu kelompok terdiri dari bapak-bapak saja atau ibu-ibu saja dan ada juga campuran antara keduanya.

Pada awalnya, kelompok buruh wanita panggilan hanya satu kelompok saja yang dikenal dengan kelompok "Saiyo". Kelompok ini berdomisili di Nagari Canduang Jorong Seratus Janjang, Kecamatan Ampek Angkek, Kabupaten Agam. Seiring bergulirnya waktu dan semakin sulitnya perekonomian menyebabkan munculnya kelompok-kelompok baru dengan pekerjaan yang sama dan mampu memperluas daerah garapan mereka sampai ke kecamatan-kecamatan tetangga. Artinya, jumlah perempuan yang menjadi orang "upahan" bertambah sebagai dampak dari ketidakberdayaan perempuan dalam persaingan ekonomi keluarga yang semakin kompetitif.

Mereka bekerja sebagai penggarap dengan upah murah mulai dari $\mathrm{Rp}$ 45.000 sampai Rp 50.000/orang/hari, sedangkan upah laki-laki Rp 60.000/ orang/hari (Wawancara dengan Daan, 15 Mei 2013). Alasan yang dikemukakan pengguna jasa buruh mengungkapkan bahwa pekerja wanita tidak sekuat buruh laki-laki. Namun, menurut pengakuan narasumber, buruh wanita bekerja secara kontinyu, sedangkan buruh laki-laki relatif sering berhenti untuk merokok (Wawancara dengan Ny. Panduko, 16 Mei 2013). Mereka bekerja dari satu daerah ke daerah lain atau dari satu ladang ke ladang lain, meskipun berada di luar kecamatan tempat domisili mereka. 
Perbedaan gaji terjadi karena hasil pekerjaan buruh wanita dianggap tidak sebanding dengan hasil pekerjaan buruh laki-laki. Para induk semang mematok upah mereka tanpa melihat hasil pekerjaan mereka, tetapi melihat dia laki-laki atau perempuan. Ketidakseimbangan penghasilan buruh perempuan dengan buruh laki-laki yang sangat mendasar terletak bukan dari jenis kelaminnya, tapi dari ideologi yang dianut perempuan dan laki-laki yang bergulir dari waktu ke waktu (Fakih, 2008: 115). Munculnya perbedaan upah laki-laki dan perempuan di antaranya karena faktor kebiasaan dalam satu daerah.

Ada beberapa faktor yang mendorong para ibu rumah tangga akhirnya bekerja menjadi buruh; pertama, hasil pertanian yang mereka miliki tidak mampu mencukupi kebutuhan ekonomi keluarga. Kondisi semakin parah ketika harga sayur-mayur yang mereka panen semakin turun dalam waktu-waktu tertentu, misalnya pada bulan Ramadhan hingga Lebaran Idulfitri usai ketika terjadi panen raya atau saat curah hujan relatif tinggi. Tanah pertanian yang mereka gunakan sebagai lahan bercocok tanam merupakan lahan kering yang berada di kaki Gunung Merapi, sehingga tingkat kesuburan tanah terus mengalami penurunan. Penggunaan pupuk kimia justru kemudian memiskinkan unsur hara dalam tanah yang pada awalnya dikenal dengan program "revolusi hijau" (Fakih, 2010: 42-43).

Kedua, mereka tidak memiliki keahlian lain selain kemampuan bertani untuk menjadi penggarap yang mereka warisi secara turun-temurun. Para pekerja hanya lulusan Sekolah Dasar (SD) atau Sekolah Menengah Pertama (SMP), bahkan ada di antara mereka yang tidak lulus sekolah sama sekali. Ada pekerjaan menjahit konveksi pakaian anak-anak untuk didistribusikan di Pasar Aur Kuning Bukittinggi, tetapi jumlah jahitan juga tidak seberapa. Sehingga mau tidak mau, ibu-ibu rumah tangga dipaksa oleh keadaan menjadi kuli di kampung sendiri atau di tanah orang lain.

Para kuli wanita tersebut tidak hanya membantu ekonomi rumah tangga dengan menjadi buruh, mereka juga menggarap lahan pertanian milik sendiri dengan luas yang tidak seberapa. Kelebihan waktu yang mereka miliki sambil menunggu panen digunakan dengan bekerja di ladang orang lain sebanyak dua kali seminggu atau berdasarkan permintaan. Tujuan bekerja keras adalah agar tidak menjadi urang kurang dalam masyarakat, atau yang disebut oleh Navis (1980:146) sebagai panutan sebagian masyarakat matrealistis di mana benda menjadi ukuran yang sangat utama.

el Harakah Vol.17 No.1 Tahun 2015 


\section{Rekrutmen Anggota dan Keorganisasian Komunitas Buruh Tani Perempuan}

Wanita yang ikut menjadi buruh kelompok harus terdaftar dalam setiap kelompok. Satu kelompok memiliki anggota antara 6 sampai 15 orang anggota. Anggota kelompok biasanya bersedia bekerja ke daerah tetangga seperti daerah Baso, Banuhampu, atau Kota Bukittinggi. Anggota buruh mayoritas berasal dari ibu rumah tangga yang sudah memiliki keluarga dan sebagian kecil juga diikuti oleh gadis yang berumur 17 tahun yang tidak memiliki pekerjaan. Tidak terlihat adanya pekerja anak-anak seperti yang terjadi di daerah lain sebagai indikasi terjadinya kelemahan ekonomi secara struktural dan kultural. Ada 3 faktor penyebab kemiskinan, yaitu pertama, kemiskinan disebabkan oleh kekurangan fisik atau mental; kedua, kemiskinan disebabkan oleh bencana alam; ketiga, kemiskinan buatan. Kemiskinan bentuk pertama disebut kemiskinan secara klasik dimana kemiskinan dikaitkan dengan struktur budaya setempat seperti malas. Bentuk kedua muncul karena adanya ketimpangan dalam struktur ekonomi. Ada sekelompok orang yang memiliki aset yang berlebih, sementara ada sekelompok orang lain yang kurang (Setiadi, 2011: 797).

Ibu-ibu yang menjadi anggota buruh tani panggilan tersebut direkrut dari satu wilayah bahkan satu desa. Mendaftar untuk menjadi anggota biasanya atas kemauan sendiri dan ada juga yang ikut atas dasar ikut-ikutan dari tetangga atau teman-teman sesama buruh wanita. Seperti pada Ibu Wirda, keikutsertaannya dalam kelompok tani hanya satu kali dalam satu minggu. Biasanya pekerjaan dilakukan pada hari Sabtu atau hari Rabu. Ibu Wirda yang sudah berumur 51 tahun dan mempunyai 3 orang anak menuturkan bahwa keikutsertaannya menjadi buruh wanita panggilan untuk membantu ekonomi keluarga. Gaji yang diperoleh digunakan untuk membayar kebutuhan pendidikan anak-anak yang sekolah di STM atau digunakan untuk kebutuhan Lebaran seperti membeli baju baru atau persiapan lain yang berkaitan dengan persoalan hari Lebaran Idulfitri (Wawancara dengan Bu Wirda, Minggu tanggal 9 Juni 2013).

Jumlah panggilan bekerja antara laki-laki dengan perempuan pada saat ini, menurut pengakuan Wirda, lebih banyak laki-laki. Pekerjaan perempuan biasanya seperti menanam padi, menanam sayuran, mengambil cabe atau manyiang (membersihkan tanaman induk dari gangguan rumput liar). Pekerjaan seperti ini lebih mengandalkan kesabaran dan ketelatenan (Naim, 1983: 7). Sedangkan pekerjaan yang membutuhkan tenaga dilakukan oleh bapak-bapak seperti marambah (membersihkan ladang dari rumput yang sudah besar), 
manabeh (membuka lahan baru untuk dijadikan lahan pertanian yang sudah lama tidak produktif), menyiangi tabu atau pekerjaan lain yang memerlukan kekuatan fisik.

Buruh wanita panggilan tidak mau bekerja setiap hari. Hari-hari yang dijadikan sebagai waktu menjadi buruh pada hari Rabu dan hari Sabtu. Anggota boleh ikut sekali atau dua kali dalam seminggu. Perempuan yang menjadi buruh setiap hari biasanya tidak masuk dalam komunitas "buruh panggilan” karena status buruh sudah menjadi profesi secara individu bagi yang bersangkutan sehingga berbeda dengan buruh wanita panggilan yang menjadikan dua hari dalam seminggu sebagai pekerja selingan dan penghasilan yang diperoleh dijadikan tabungan Lebaran.

Anggota buruh wanita di hari lain kadangkala juga melakukan penggarapan ladang atau sawah secara "bakonsi", yaitu anggota kelompok secara bergantian bekerja di ladang atau sawah anggota kelompok lainnya. Terkait permasalahan waktu dan siapa yang akan ikut, selanjutnya dilakukan berdasarkan kesepakatan dari anggota kelompok. Bergotong-royong mengerjakan lahan anggota kelompok buruh secara bergantian di daerah lain di Sumatera Barat dikenal dengan juga dengan istilah manaruko atau bajulo-julo.

Menurut Bu Eda, di Jorong Bingkudu Kanagarian Canduang Koto Laweh sendiri terdapat 5 kelompok buruh tani panggilan. Dari 5 kelompok tersebut terdapat 2 kelompok buruh tani panggilan perempuan. Setiap jorong memiliki buruh tani panggilan. Di Nagari Canduang Koto Laweh sendiri memiliki 11 jorong seperti Jorong Seratus Janjang, Jorong Labuang, Bingkudu dan seterusnya. Jika sepertiga buruh tani panggilan dari 11 jorong yang ada, maka ada 4 kelompok buruh wanita panggilan dalam satu nagari. Jika satu kelompok berjumlah 8 orang, maka ada 32 orang dalam satu nagari yang menjadi buruh wanita panggilan. Tidak termasuk buruh wanita panggilan dari Nagari Lasi atau nagari lain di sekitar Canduang (Amir, 1999: 171).

\section{Pituah "nan tuo" (orang yang dituakan) ketika Menjadi Buruh Wanita Panggilan}

Layaknya sebuah organisasi yang lengkap, kelompok buruh perempuan juga memiliki "standar" untuk dapat menjadi buruh. Mulai dari disiplin berangkat kerja sampai pulang dari bekerja. Para buruh wanita juga sangat menjaga reputasi kelompok dengan induk semang dengan cara bekerja dengan penuh tanggung jawab. Mereka tidak ingin pemilik lahan kecewa dengan pekerjaan mereka seperti sering berhenti sambil berbicara, terlalu lama istirahat untuk 
shalat, atau terlalu lama ketika makan siang. Filosofi yang mereka gunakan adalah "pitih sumbiang" yaitu menghindari banyak istirahat yang tidak berkaitan dengan kegiatan yang menunjang tugas mereka sebagai buruh dalam satu pekerjaan. Gaji yang diberikan pemilik lahan dianggap seperti lingkaran; jika performa buruh jelek dalam bekerja, maka gaji yang diperoleh dianggap tidak bulat lagi tapi sudah kurang sedikit seperti berkurangnya sebuah lingkaran.

Para buruh juga menggunakan "raso jo pareso" dalam menerima upahan. Dalam filosofi Minangkabau, raso (rasa) dijadikan sebagai timbangan yang muaranya di hati. Sedangkan pareso timbangannya adalah akal. Pareso penilaian terhadap hal-hal yang bersifat etis yaitu kesusilaan dan hati nurani. Jika sudah terpenuhi raso jo pareso, masih ada timbangan lain yang dikenal dengan patut dan mungkin. Tidak semua yang patut mungkin untuk dilaksanakan, sedangkan mungkin lebih bersifat kondisional dalam melakukan sesuatu. Di Minangkabau disarikan dengan ungkapan "raso dibao naiak, pareso dibao turun" (Bandaro, 2002: 65). Jika para buruh terlambat sampai di tempat tujuan karena faktor transportasi umpamanya, mereka juga akan terlambat pulang untuk menutup keterlambatan mereka di awal bekerja. Bukan itu saja, perbuatan baik yang diberikan pemilik lahan dengan memberikan nasi bungkus kepada buruh, juga akan mereka balas dengan cara bekerja lebih lama dibandingkan dengan pemilik lahan yang tidak perduli terhadap kondisi mereka.

Ada "standar" bekerja kelompok buruh tani perempuan panggilan untuk menjaga kepuasan pemilik lahan yaitu: pertama, disiplin dalam persoalan waktu. Waktu untuk mulai bekerja selalu jam 08.00 pagi dan berhenti pada jam 16.00 sore. Kedua, menjaga kepuasan konsumen terhadap hasil kerja mereka. Setiap anggota kelompok buruh sudah memahami untuk tidak berhenti bekerja secara serentak, tapi istirahat dilakukan secara bergantian hingga tidak menimbulkan kesan negatif terhadap produktivitas bekerja. Hal yang sama juga menjadi perhatian mereka seperti melakukan shalat atau makan siang dengan cara bergantian. Jika ada salah seorang anggota kelompok yang kurang sehat, ketua kelompok biasanya menyarankan untuk istirahat sementara sampai kondisi buruh sehat kembali. Hal ini dilakukan ketua kelompok karena mempertimbangkan individu buruh dan kesan pemilik lahan terhadap produktivitas buruh dalam bekerja. Sakit dapat mengurangi kepercayaan pemilik lahan terhadap "daya jual" kelompok terhadap konsumen lainnya. Ketiga, bagarah atau bergurau sekedarnya. Ketika berada di wilayah orang lain, tentu ada kearifan lokal setempat yang harus dijaga, khususnya yang berkaitan dengan bahasa dan perbuatan. Di Minang sendiri ada istilah 
"garah kudo" yang dianggap bahasa kasar, tetapi bagi orang yang bersangkutan dianggap sebagai gurauan biasa. Garah kudo seperti kuda yang bercanda tanpa memperdulikan kuda lainnya. Kuda yang sedang bercanda tanpa sengaja tertendang kuda lainnya. Antisipasi garah kudo bertujuan agar pemilik lahan tidak merasa tersinggung dengan tindakan buruh upahan ketika bercanda di lingkungan pemilik lahan. Di Minangkabau dikenal dengan "adai salingka nagari, lain padang lain belalang”, yaitu kebiasaan yang ada di satu daerah mungkin tidak sama dengan kebiasaan di daerah lain, sekalipun masih dalam satu bahasa dan budaya yaitu Minangkabau.

\section{Pekerjaan Tambahan yang dilakukan Buruh Tani Panggilan}

Pada masyarakat Canduang, buruh wanita tidak hanya bergerak dalam sektor pertanian semata. Ada sektor lain yang menjadi objek pekerjaan masyarakat seperti buruh di bidang peternakan. Buruh perempuan biasanya mengembangkan ternak unggas, seperti itik kampung. Modal awal beternak diambil dari dana kelompok buruh yang sebagian dialihkan ke sektor peternakan. Hasil yang diperoleh dibagi berdasarkan modal yang dimasukkan anggota buruh wanita dalam satu jenis peternakan. Seperti beternak itik umpamanya, jika 30 ekor bebek kampung yang diternakkan dan semuanya produktif bertelur, maka masing-masing anggota mendapatkan 5 butir jika satu kelompok memiliki 6 orang anggota. Setiap anggota dianggap memiliki saham dalam pengembangan ternak. Jika modal pengembangan bebek dianggap sudah lunas, maka bebek selanjutnya menjadi milik peternak. Dalam bentuk yang seperti ini, peternak dianggap sebagai peminjam modal terhadap kelompok yang dibayar dengan cara mencicil kepada pemilik saham dengan cara menyetor telur bebek setiap hari, jika bebek yang diternakkan produktif bertelor setiap hari. Dana ini dianggap sebagai modal bergulir yang berlaku hanya terhadap anggota kelompok buruh tani saja.

Modal peternakan diambil dari gaji kelompok yang terkumpul. Jika diakumulasikan dalam rentang satu tahun, jumlahnya dapat mencapai puluhan juta rupiah, sektor peternakan juga menyentuh modal yang lebih besar seperti beternak sapi dan kambing. Kelompok buruh juga mencoba meminta modal kepada pihak pemerintah daerah melalui kepengurusan kelompok kepada pemerintah daerah, sekalipun modal yang diperoleh tidak merata untuk semua kelompok. Dalam bentuk yang seperti ini, pengurus kelompok juga menyiapkan stempel kelompok sebagai bukti pertanggungjawaban terhadap Kepala Daerah Tingkat II di Kabupaten Agam. Berdasarkan penuturan Zetri, 
modal yang dikucurkan sangat sedikit dan harus melalui birokrasi relatif panjang untuk sampai pada pencairan dana untuk kelompok tani.

Pekerjaan alternatif lain yang dimiliki anggota buruh laki-laki adalah di bidang kesenian. Jasa mereka digunakan dalam acara kenduri dengan memukul rebana berkeliling kampung sampai ke rumah marapulai (pengantin laki-laki). Jasa kelompok kesenian ini dihargai secara variatif dengan melihat kemampuan ekonomi keluarga pengantin. Dalam satu acara baralek, kelompok yang terdiri dari 6 orang dibayar sebanyak Rp 500.000. Artinya satu orang mendapatkan penghasilan sekitar $\mathrm{Rp}$ 83.000. Jika yang mengundang rebana berlatar belakang ekonomi menengah ke atas, semua anggota kelompok yang berjumlah 12 orang diikutsertakan semuanya dan dibayar sekitar Rp 1.400.000.

Pekerjaan lain dari buruh wanita adalah menjahit pakaian yang dijual pemilik ke Pasar Aur Kuning di Kota Bukittinggi. Jumlah buruh perempuan yang bergerak dalam sektor konveksi ini relatif sedikit dibandingkan dengan jumlah buruh kasar. Masyarakat Candung lebih dikenal sebagai penjual jasa di bidang pertanian dibandingkan jasa lainnya di Agam Timur. Sedangkan nagari tetangga seperti Batu Taba, lebih dikenal masyarakat sebagai pengolah konveksi dan Nagari Sungai Puar dengan home industri yang dikenal dengan penyedia alat-alat pertanian dari besi yang popular dengan apa basi.

\section{Majikan 'Nakal'}

Tidak semua pekerjaan buruh tani memiliki citra rendah di mata masyarakat. Menjadi buruh tani panggilan justru dapat menghilangkan stress dan menghilangkan kejenuhan setelah bekerja di ladang sendiri. Pertemuan antar buruh tani yang berasal dari satu kampung berlainan jorong justru menimbulkan gelak-tawa sendiri. Ada cerita-cerita baru yang didengar dari sesama buruh setelah satu minggu tidak bertemu. Ketika diminta untuk menjadi buruh setiap hari, mereka juga tidak mau dengan ungkapan "kami bukan buruh tani harian".

Menjadi buruh tani panggilan di Candung dalam kelompok juga menjadi ajang silaturahmi dan tempat sosialisasi antarburuh. Wadahnya buruh tani, namun substansinya membangun komunikasi antarwarga. Ketika berkumpul dalam satu kelompok, para buruh tani kadang juga saling berdiskusi menyangkut berbagai persoalan; mulai dari persoalan pertanian sampai persoalan kegemaran masing-masing, mulai dari persoalan sekolah anak-anak sampai persoalan rumah tangga yang lebih bersifat tertutup, seperti persoalan bagaimana menanggulangi hama cabe yang semakin bervariasi, 
tentang rumput liar yang lebih baik direndup (diberi racun daun) atau disiangi, cerita perburuan babi, dan lain-lain.

Seloroh yang diungkapkan Pak Zet adalah: buruh tani di sini "orang bansai tinggi ati” (orang miskin yang angkuh). Ungkapan ini keluar karena memang secara realitas para buruh tani hidup dalam kondisi ekonomi yang serba terbatas, tetapi mereka juga tidak mau bekerja setiap hari untuk menjadi buruh panggilan di ladang orang lain. Alasan yang mereka gunakan adalah "kami juga punya pekerjaan di ladang kami sendiri", sekalipun ladang yang diproduktifkan itu merupakan ladang orang lain dengan sistem paroan dengan pemilik lahan.

Sambil bekerja, anggota kelompok juga membuat "daftar hitam" dalam ingatan mereka siapa-siapa saja majikan yang tidak mau membayar keringat mereka. Sebagai buruh panggilan yang mendapat gaji sekali setahun, ketua kelompok memberitahukan bahwa gaji kita yang bekerja pada hari itu dan di tempat itu tidak dibayar dengan alasan pemilik lahan pada saat ini tidak memiliki uang. Informasi koordinator kelompok tentang gaji mereka yang tidak dibayar menyebabkan anggota membuat daftar pemilik lahan yang dikasifikasikan sebagai majikan-majikan nakal atau majikan bermasalah. Kejadian yang seperti ini bukan sekali dialami oleh buruh tani panggilan, baik dari kalangan bapak-bapak atau ibu ibu.

Ketua kelompok sangat terbuka dalam persoalan rekrutmen anggota buruh, termasuk dalam persoalan keuangan. Jika terjadi persoalan dalam kelompok buruh tani, seperti penolakan pembayaran gaji oleh pemilik lahan, ketua kelompok biasanya memberitahukan kepada anggota kelompok bahwa pekerjaan pada hari itu, tanggal sekian, di tempat yang dimaksud tidak dibayar oleh pemilik lahan. Dari pengalaman kelompok buruh tentang persoalan penolakan pembayaran gaji oleh pemilik ladang, di samping mereka menolak bekerja pada pemilik lahan yang nakal, kelompok buruh juga menyiasati agar keringat mereka tidak terbuang percuma dengan cara meminta gaji di awal bekerja.

\section{Penerimaan Gaji Setahun Sekali}

Ada perbedaan dalam pembayaran gaji antara buruh tani di Kecamatan Canduang dengan buruh dari daerah lain. Buruh tani wanita panggilan dari Canduang dan Lasi menerima pembayaran gaji ketika menjelang hari Lebaran Idulfitri setiap tahunnya. Jika mereka bekerja setiap hari Sabtu dan Minggu, dengan upah Rp. 45.000/hari, maka hasil yang diperoleh setiap 
bulan adalah $\mathrm{Rp}$ 180.000. Jika buruh bekerja penuh sepanjang bulan maka gaji yang diperoleh selama setahun adalah $\mathrm{Rp} 2.160 .000$. Jika buruh bekerja dua kali dalam satu minggu, maka gaji yang diperoleh dalam setahun tentu dua kali lipat dari gaji di atas.

Kelompok buruh tani wanita panggilan selain bergaji $\mathrm{Rp} 45.000 /$ hari, ada juga yang mematok upah buruh wanita panggilan sebanyak $\mathrm{Rp} 50.000 /$ hari. Sedangkan untuk pekerja laki-laki, upah yang diminta adalah $\mathrm{Rp} 60.000 /$ hari. Upah yang diminta biasanya di luar biaya transportasi dari domisili pekerja sampai ke lahan pemilik ladang. Jika pemilik lahan kesulitan dalam mencarikan mobil, ketua kelompok tani juga dapat membantu mencarikan mobil dengan biaya dari pemilik lahan.

Pada bulan Ramadhan, ketua kelompok biasanya melakukan penagihan gaji yang masih berada pada pemilik lahan. Jika pemilik lahan kesulitan untuk membayar gaji pada minggu pertama bulan Ramadhan, biasanya ketua kelompok memberikan toleransi untuk dibayar pada minggu berikutnya. Yang terpenting, seminggu sebelum Lebaran semua gaji pekerja sudah dibagikan kepada para buruh.

Gaji yang berhasil ditagih oleh ketua kelompok, biasanya langsung disetorkan ke Koperasi Unit Desa (KUD) yang terletak di Simpang Canduang. Jika ada 10 orang pekerja dengan gaji $\mathrm{Rp} \mathrm{45.000/orang,} \mathrm{maka} \mathrm{satu} \mathrm{orang} \mathrm{majikan} \mathrm{akan}$ membayar sebanyak Rp 450.000. Jika buruh bekerja selama empat kali dalam satu bulan maka uang yang terkumpul sebanyak $\mathrm{Rp}$ 1.800.000. Jika dikalikan dengan 12 bulan selama setahun, maka uang yang terkumpul sebanyak Rp 21.600.000. Jumlah ini dapat bertambah atau berkurang tergantung seberapa banyak frekuensi bekerja yang dilakukan oleh satu kelompok tani. Buruh juga diperkenankan untuk meminta gaji selesai bekerja, jika pembayaran gaji sudah dilakukan oleh pemilik lahan. Jadi, penagihan gaji oleh anggota buruh tidak harus setiap menjelang Lebaran, tetapi berdasarkan kebutuhan dari individu buruh yang bersangkutan.

\section{Buruh Wanita dalam Kultur Minangkabau}

Perempuan dalam kultur Minangkabau mendapatkan tempat yang sangat tinggi. Banyak adagium yang menunjukkan penghormatan terhadap kaum hawa dengan peran yang sangat strategis dan urgen seperti ungkapan: limpapeh rumah nan gadang, sumarak anjuang nan tinggi, sumarak kampuang pamenan nagari 
Bagi perempuan yang sudah berkeluarga, sebutan yang biasa digunakan adalah "bundo kandung". Bundo kandung memiliki tanggung jawab yang berbeda dengan gadis, baik perannya sebagai istri dalam keluarga ataupun perannya dalam adat dan nagari.

Sumatera Barat dengan permukaan geografisnya yang terdiri atas perbukitan, jurang, danau, dan pegunungan menyebabkan konsep awal kehidupan masyarakatnya berbentuk agraris. Kondisi alam yang beragam menyebabkan masyarat mempunyai pandangan tersendiri terhadap kehidupan. Pola ini kemudian melahirkan konsep merantau dengan perdagangan sebagai salah satu alternatif.

Bagi masyarakat yang bertahan di kampung, kehidupan pertanian menjadi andalan utama, khususnya masyarakat pedesaan yang jauh dari hiruk-pikuk kota. Penggunaan istilah buruh dipinjam dari penggunaan istilah yang lazim digunakan di daerah perkotaan yang memang banyak tempat-tempat industri dengan melihat adanya kesamaan peran, fungsi dan hubungan pekerja dengan majikan. Dalam masyarakat Minang, buruh tani dalam terminologi bahasa Indonesia biasa disebut dengan "urang ka parak". Secara substansi antara buruh dan urang ka parak di Sumatera Barat pada satu sisi hampir sama, meskipun pada sisi yang lain mempunyai perbedaan.

Perempuan di Minangkabau dengan sistem kekerabatan matrilineal dipersiapkan laksana ratu, perannya lebih banyak bersifat ke dalam dibandingkan laki-laki yang mengatur keluar. Perempuan dipersiapkan sebagai pelanjut keturunan dengan segala atribut yang melekat pada posisi ibu dan istri dalam keluarga. Kemudian yang memegang kekuasaan yang bersifat ke bawah, di tengah dan ke atas adalah laki-laki. Rumah gadang dikepalai oleh tungganai. Pada tingkat suku yang memimpin adalah penghulu. Dalam level nagari, kekuasaan tertinggi dipegang oleh penghulu pucuak. Dalam lingkungan adat di Minangkabau yang berkuasa adalah raja yang Tiga Sila. Semuanya dalam garis laki-laki, sehingga kurang tepat jika Minangkabau disebut menggunakan sistem matrilineal tetapi lebih tepat dengan sistem matriachat. Alasan yang digunakan untuk menolak kekerabatan di Minangkabau dengan sistem matrilineal yaitu; pertama, tidak munculnya tokoh perempuan dalam asal-usul kejadian nenek moyang Minangkabau; yang muncul sepanjang sejarah adalah laki-laki. Kedua, adanya kecenderungan untuk mencarikan laki-laki yang baik untuk dijadikan urang sumando yang tujuannya adalah untuk mendapatkan ketutunan yang baik pula. Ketiga, terjadinya penurunan pangkat kepada anak dalam kepemimpinan (Syarifuddin, 1984: 183). 
Ketika hasil pertanian tidak lagi dapat memenuhi kebutuhan keluarga besar rumah gadang, keluarga muda memisahkan diri dari rumah gadang dengan membentuk sub-sub keluarga mandiri. Selanjutnya pertanggungjawaban ekonomi keluarga juga turut berubah, mamak kemudian lebih "berjibaku" untuk membesarkan anak-anaknya sendiri dibandingkan membesarkan keponakan dari garis ibu. Sedangkan kelangsungan ekonomi keponakan juga diserahkan kepada sumando yang masuk dalam keluarga besar garis perempuan. Perkawinan di Minangkabau dikenal dengan perkawinan eksogami, di mana calon suami berasal dari luar suku mempelai perempuan. Ketika suami masuk dalam keluarga besar perempuan, mereka disebut dengan "urang sumando". Sumando tidak mempunyai kekuasaan di bidang harta pusaka hingga mereka diistilahkan dengan "abu di ateh tunggua" (abu di atas tunggul), yang secara harfiah berarti "jika angin datang, abu terbang". Sumando yang mempunyai wibawa dan didengar oleh keluarga istri mereka disebut dengan "sumando niniak mamak", tetapi kekuasaannya terhadap harta pusaka isteri tetap tidak dapat diutak-atiknya, kecuali harta pencaharian atau harta bawaannya yang disebut "harta suarang" (Toeah, 1976: 192).

Dari kondisi inilah kemudian munculnya perempuan-perempuan buruh, ketika sumando memiliki penghasilan ekonomi yang terbatas, istri dipaksa oleh keadaan untuk turut serta memikirkan ekonomi keluarga. Keluarga yang tidak mendapatkan proteksi dari keluarga besar pasukuan atau secara ekonomi juga berada dalam kemiskinan rentan berada dalam proses pemiskinan. Inilah sebuah ironi daerah subur menjadi lumbung gizi buruk yang diungkap Departemen Kesehatan RI tahun 2004, bahwa Sumatera Barat termasuk urutan 11 dari 30 provinsi lain tentang data gizi buruk. Persentase penderita gizi buruk sebanyak 7.03\% berada di bawah Provinsi Maluku Utara. Dalam hitungan kuntitatif, penderita gizi buruk berjumlah 54.000 orang. Masyarakat hanya memakan beras pecah dari Vietnam sedangkan beras lokal yang berkualitas seperti beras Solok dan Nundam dijual ke Batam, Medan, atau bahkan diekspor ke Malaysia (Jhamtani, 2008: 88).

Adat Minangkabau juga memberikan respon yang sangat besar terhadap orang yang bekerja mencari rezeki dan menambah harta pusaka, sebagaimana yang diungkapkan pepatah "warih dijawek (waris diterima) pusako ditolong (pusako ditolong) (Noesjirwan, 1983: 31).

Bukan itu saja, kesejahteraan dan kemakmuran material dan fisik juga ditentukan oleh harta, termasuk status sosial dan harga diri. Kesadaran terhadap urgensi harta inilah yang mendorong orang Minang bekerja keras 
untuk memenuhi kebutuhan keluarga, termasuk yang berada di kampung sebagaimana yang diungkapkan pepatah:

Kayu hutan bukan andaleh (kayu hutan bukan andalas)

Elok dibuek kalamari (baik dibuat untuk lemari)

Amuah bahujan tahan bapaneh (mau berhujan tahan panas)

Baitu urang mancari rasaki (seperti itu orang mencari rezeki)

Dalam adat Minangkabau, semua lahan dianggap mempunyai nilai ekonomi berdasarkan kondisinya masing-masing sebagaimana diungkapkan pepatah:

Sawah ladang banda buatan (sawah ladang banda buatan)

nan lunak ditanami baniah (yang lunak ditanami benih)

nan kareh dijadikan ladang (yang keras dijadikan ladang)

Ka rimbo babungo kayu (ke hutan berbunga kayu)

Ka sungai babungo pasia (ke sungai berbunga pasir)

Ka lauik babungo karang (ke laut berbunga karang)

Ka tambang babungo ameh (ke tambang berbunga emas)

(Syarifuddin, 1984: 159)

Bahkan hutan sekalipun dapat dimanfaatkan untuk kehidupan perekonomian yang dalam adat dikenal dua bentuk hutan yaitu; hutan tinggi dan hutan rendah. Hutan tinggi adalah segala tanah yang belum diolah dan belum dijadikan lahan pertanian. Hutan ini belum memberikan nilai ekonomi secara maksimal kepada masyarakat yang berada di sekitarnya. Sedangkan hutan rendah adalah hutan yang sudah "ditaruko" oleh masyarakat pada masa lalu dan dijadikan sebagai lahan pertanian atau perumahan.

Terkait dengan bentuk pekerjaan, masyarakat Minang melihat semua orang memilki potensi secara ekonomi dan memiliki nilai efisiensi. Baik orang itu berpendidikan atau tidak sekolah. Orang itu cacat atau sehat secara fisik dan seterusnya, sebagaimana filosofi Minang yang diungkapkan dalam pepatah:

Nan buto pahambuih lasuang (yang buta untuk meniup lesung)

Nan pakak palapeh badia (yang tuli untuk melepaskan senapan)

Nan lumpuah paunyi rumah (yang lumpuh menghuni rumah)

Nan kuaik pambawo baban (yang kuat membawa beban)

Nan binguang kadisuruh-suruah (yang bodoh untuk disuruh-suruh)

Nan cadiak dibawo barundiang (yang cerdik dibawa berunding)

Nan tua tampai babarito (yang tua tempat berberita)

Nan cadiak tampai batanyo (yang cerdik tempat bertanya)

Nan pandai tampai baguru (yang pandai tempat berguru)

(Noesjirwan, 1983: 26) 
Pepatah Minang tersebut tidak membedakan antara perempuan dan laki-laki. Semua orang dianggap mempunyai nilai dan dapat berkonstribusi terhadap perekonomian keluarga. Ketika bundo kanduang keluar dari rumah untuk menunjang perekonomian keluarga, secara adat tidak disebut sumbang atau cela, tetapi posisi perempuan yang tinggi di dalam kultur Minangkabau mulai tergerus oleh globalisasi. Ungkapan Naim; "bahwa fungsi dan peran wanita sebagai "limpapeh", "amban puruak " dan "sumarak" rumah nan gadang dan konsekuensinya akan memudar karena semua ini dapat berlaku dalam struktur lama dalam kehidupan berkaum dan bersuku. Jika sendi-sendi dasar ini telah berubah, maka fungsi-fungsi perempuan dalam adat dengan sendirinya juga akan berubah" (Naim, 1983: 15).

\section{Simpulan}

Fakta yang ada di Jorong Bingkudu, Seratus Janjang, dan jorong-jorong lainnya yang ada di Kanagarian Canduang Koto Laweh Kabupaten Agam terdapat dua bentuk buruh tani perempuan berdasarkan tipologi yang dianut masyarakat. Pertama, perempuan yang menggantungkan ekonomi mereka dari buruh tani secara individu. Buruh dalam bentuk seperti ini memang mengandalkan kehidupan mereka dari usaha menjadi buruh dari ladang ke ladang orang lain. Upah yang mereka peroleh dijadikan sumber kehidupan sehari-hari. Kedua, buruh tani panggilan yang tidak menggantungkan "asap dapur" mereka dari pekerjaan menjadi buruh. Menjadi buruh tani panggilan dilakukan sekali seminggu atau dua kali seminggu. Di samping menjadi buruh mingguan, mereka mengolah lahan sempit milik sendiri atau dari sistem paroan dengan sawah orang lain. Buruh tani yang seperti ini menjadikan pekerjaan buruh sebagai selingan untuk mengisi waktu luang sembari menunggu panen di lahan sendiri dan untuk memenuhi kebutuhan Lebaran Idulfitri seperti membeli baju baru atau persiapan lain yang berkaitan dengan persoalan hari Lebaran Idulfitri.

Ketika disandingkan profesi buruh perempuan dengan posisi bundo kanduang dalam kultur Minangkabau yang menghargai posisi perempuan, tidak dapat dipungkiri telah terjadi reposisi terhadap aktifitas perempuan dalam dunia kerja. Perempuan dan ibu-ibu tidak lagi berada dalam lingkungan rumah gadang, tapi mereka sudah keluar dari status quo adat dengan alasan ekonomi, pendidikan, perkembangan budaya dan seterusnya. Peningkatan pendidikan tidak dapat dipungkiri membawa pengaruh terhadap peningkatan ekonomi 
keluarga. Keinginan melestarikan adat Minangkabau dan pewarisan kepada generasi muda diamini oleh banyak pihak.

Memetakan aktifitas dan semangat kerja buruh tani bisa dijadikan modal awal untuk melakukan gerakan pemberdayaan berbasis perempuan untuk mempengaruhi publik atau memberikan kesadaran kritis terhadap pentingnya pendidikan. Termasuk upaya-upaya peningkatan pengetahuan pertanian yang membantu dalam kemandirian ekonomi keluarga. Keberpihakan adat kepada perempuan juga bukan berarti meletakkan mereka dalam sangkar emas dengan bergantung penuh terhadap keluarga besar rumah gadang atau kerabat lainnya. Adat minang sangat menghargai semangat kerja sebagai wujud dari tanggung jawab terhadap individu, keluarga, bahkan dalam bernagari.

\section{Daftar Pustaka}

Bachtiar, Harsja W. 1983. Wanita dalam Keluarga Minangkabau. Di dalam: Kumpulan naskah Simposium. Pengaruh Adat Istiadat Minangkabau terhadap Kehidupan Wanita dalam Mengembangkan Budaya Bangsa. Jakarta: Yayasan Bunda.

Bandaro, Ch N. Latief Dt. 2002. Etnis dan Adat Minangkabau, Permasalahan dan Masa Depannya. Bandung: Angkasa

Fakih, Mansour. 2008. Analisis Gender dan Transformasi Sosial. Yogyakarta: Insist Press

Fakih, Mansour. 2008. Runtuhnya Teori Pembangunan dan Globalisasi. Yogyakarta: Insist Press

Fakih, Mansour. 2010. Bebas dari Neoliberalisme. Yogyakarta: Insist Press

Jhamtani, Hira. 2008. Lumbung Pangan, Menata Ulang Kebijakan Pangan, Yogyakarta: Insist Press.

Mikkelsen, Britha. Metode Penelitian Partisipatoris dan Upaya Pemberdayaan Panduang bagi Praktisi Lapangan. Jakarta: Yayasan Pustaka Obor Indonesia.

M.S, Amir. 1999. Adat Minangkabau; Pola dan Tujuan Hidup Orang Minang. Jakarta: PT Mutiara Sumber Widya.

Navis, AA. 1980. Adat dan Kebudayaan Minangkabau. Kayu Tanam, Ruang Pendidikan INS Kayu Tanam 
Naim, Mochtar. 1983. Wanita Minangkabau dan Lapangan pekerjaan. Jakarta; tidak diterbitkan

Noesjirwan, Z. F. Joesoef. Peranan Wanita Minangkabau dalam Menghadapi Tantangan Masa Depan, makalah (tidak diterbitkan)

Setiadi, Elly M. 2011. Pengantar Sosiologi, Pemahaman Fakta dan Gejala Permasalahan Sosial: Teori, Aplikasi, dan Pemecahannya. Jakarta: Kencana Predana Media Group.

Syarifuddin, Amir. 1984. Pelaksanaan Hukum Kewarisan Islam dalam Lingkungan Adat Minangkabau. Jakarta: Gunung Agung.

Toeah, H. Datoek. 1976. Tambo Alam Minangkabau. Bukittinggi: Pustaka Indonesia. 